\title{
Teacher training for religious education: Engaging academics through the Dialogical Self Theory
}

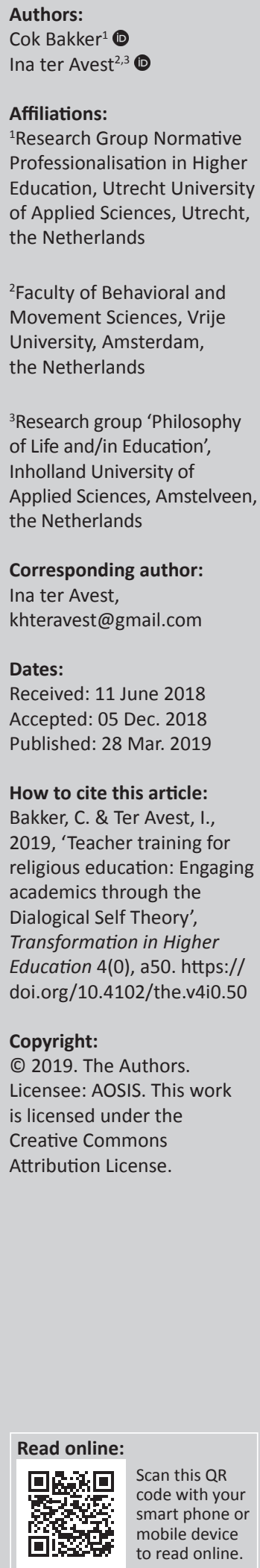

Background: In the Netherlands, most of the academic curricula for teacher training in religious education (RE) focus on shortfalls of students, like a lack of knowledge about the plurality of worldviews and the diversity in interpretations of the Christian tradition.

In our research project, the focus is not on the students, but on the university professors and lecturers who teach the subject of RE: professors and lecturers who train and educate students to teach RE.

Aim: The main aim of the project was to gain a better insight into the inherent complexity of the professionalism of academics, that is, their own positionality in the plurality of the Roman Catholic traditions they adhere to in relation to their capabilities and commitment to the current curriculum - the 'old' one - and the new curriculum to be developed, in the context of the Dutch plural society.

Setting: Respondents in this research were university professors and lecturers of the Teacher Training Institute of Tilburg University, located at Utrecht, the Netherlands.

Methods: For this investigation, we used a research instrument based on the dialogical self theory and its self confrontation method for organisations to gain insight into professionals' own and their colleagues' positionality regarding teaching RE.

Results: Preliminary results show that the self confrontation method for organisations has shown itself to be a challenging instrument to invite academics involved in the process of data construction and data analysis.

Conclusion: Based on these results, we recommend to include the research population in a validation process to increase the sustainability of the results and to maximise engagement in the implementation phase of the new curriculum.

Keywords: religious education; teacher training; academics' positionality; normative professionalism; Dialogical Self Theory; Valuation Theory.

\section{Introduction}

In the Netherlands, over the past decade, only a small number of the students who enrol in a teacher training programme at a university have been raised in a family and educational context that is religiously homogeneous. This development is not surprising because the Netherlands is one of the most secularised countries of Europe (Jackson et al. 2007; Van de Donk et al. 2006). Although Christianity and Christian values are part of the Dutch national identity, nowadays the majority of students are raised in a non-confessional family, attend a secularised Christian or public secondary school and meet peers in membership organisations that are unrelated to the Church or any other religious community. They know little about the Christian tradition or the role it played in the history of the Netherlands. However, a considerable number of these students are not indifferent to secular and religious rituals and symbols in general (Ter Borg et al. 2008). On the contrary, they prove to be highly interested in worldviews, rituals, religiosity, spirituality and related traditions. This generation of students is designated as 'unaffiliated spirituals' (Van de Donk et al. 2006). They believe without belonging, or, in other words, their belief system is flexible and includes a variety of elements from different traditions. As a generation they represent a life orientation typified by a so-called 'multiple religious belonging' (Kalsky \& Pruim 2014). These students are confronted with different discourses regarding the 'truth claims' of traditions (Versteegt 2010:72-74), and sometimes even encounter conflicting opinions and statements. This is the situation for students in different departments, including those entering teacher training for religious education (RE). 
In this highly secularised and pluralistic worldview context, students have to choose between a variety of (semi-) academic contexts to obtain an academic degree, so as to become a licensed teacher in this domain. The academic institutions in question are not that different in their pedagogical approach; however, the difference lies in their life orientation-related view on education. In the Netherlands, academic teacher training programmes are nearly always offered by faculties of universities with an explicit Protestant, Humanistic or Roman Catholic ethos. The Teacher Training Department, which is the object of our study, is closely connected to the Faculty of Theology of one of the smaller Dutch universities - in this case, a university and a faculty with an explicit Roman Catholic focus. This Roman Catholic Teacher Training Institute (RC-TTI), nevertheless, admits students from any religious or secular worldview background. The dominant Catholic atmosphere of this faculty, however, might be problematic for secular ised Christian students in some cases, and even more so for students who enter university with a well-defined, but unreflected and exclusively interpreted (Christian) religious conviction, or with a so-called 'foreclosure' in the development of their religious or semi-secular worldview in general (Bakker \& Ter Avest 2008; Marcia 1980).

\section{The professionalism of academic scholars}

Instead of focusing on the deficiencies of students, like their lack of knowledge about religious and secular traditions, in our research we focus on academics who teach the subject of $\mathrm{RE}$ and on the religious beliefs and convictions which they hold. It is the task of university professors and lecturers to train their students to become 'good RE teachers' - good teachers for students in secondary education - be it in schools with a Christian identity or in state schools - all of them populated by students with a variety of religious and secular backgrounds. In everyday practice, this means that in the 4-year RE training programme priority is given in the first place to the development of so-called instrumental professionalism, with its focus on techniques of how to teach in an informative way. Religious education students have to study and practise pedagogical strategies, classroom management and leadership styles. Students receive information about the educational and political arena in the Netherlands. In addition, RE students are taught about the Christian tradition - for some students this is the tradition their parents were associated with in one way or another and about other secular and religious traditions which people in the Netherlands adhere to, with Islam being the second most important religion in the Netherlands after Christianity. Last but not least, over the course of a 4-year training, attention should be given in the curriculum of teacher training in RE to the development of the students' so-called normative 1 professionalism, focusing on their own position in the religious arena and their own way of coping with diversity. This is concretised in the reflection which students in the course of their teacher training develop about their biographically rooted value orientation and its relation to the institution they enter as an RE teacher, and about their own positionality in the field of religious and secular worldviews - and the politics of education in the Netherlands in general (see, e.g., Kelchterman 2013; Van der Zande 2018). Instrumental professionalism is included in this more versatile development called normative professionalism (Bakker 2014, 2016; Van Den Ende \& Kunneman 2007; Van Ewijk \& Kunneman 2013). To train RE students in their instrumental professionalism and coach them in the reflection on their value-related positionality (normative professionalism), academics themselves should be aware of their own positionality with regard to the above-mentioned aspects of instrumental and normative professionalism (cf. Ter Avest et al. 2009; Van der Want et al. 2009).

The stimulation and support of academics (professors and lecturers) in the development of their own normative professionalism to facilitate the professional identity development of RE students include a provocation (or even seduction) to leave the 'comfort zone' of long-standing beliefs and face uncertainty, which makes them vulnerable (Hermans \& Gieser 2012; Kelchtermans 2009). In this process, they become aware of their longing for what is left behind (retrospective nostalgia) as well as of their longing for a new situation (prospective nostalgia; Du Preez 2011), that is, the situation that the newly implemented curriculum of their TC-TTI attains a high status (in the Netherlands, and in Europe as well). Our research question is a methodological one derived from the theoretical perspective of the Dialogical Self Theory: how to invite, challenge or even provoke academics to leave their comfort zone, make them face and show their vulnerability, and how to get academics to commit to a new curriculum in an enthusiastic way which is motivating for their students as well. Subquestions are related to the self-understanding of academics (cf. Vloet, Jacobs \& Veugelers 2016), including the awareness they have of their comfort zone (their actual way of interpreting and adhering - in some way or another - to the Roman Catholic tradition), the different ways in which they commit themselves and corresponding various degrees of commitment, and their knowledge of the core aspects of the new curriculum to be developed. The aim of our study is to stimulate the self-understanding of academics and to make them aware, as individuals, of their actual positionality regarding the Roman Catholic tradition (the 'voice of tradition'), as well as of their team's positionality in relation to the education and training of the students in this RC-TTI, in the context of the Dutch pluralistic society. With this study, we contribute to the body of knowledge regarding the (pre) conditions like self-knowledge, self-awareness and selfesteem which have to be in place, in order for academics to commit to new and innovative developments in education.

\section{Theoretical framework}

In the Western world, identity development is considered to be a core aspect of education, wherein identity development 
is understood as subjectification (Biesta 2014). Identity development in the sense of subjectification is a major educational objective in the West, for primary education up to higher and academic education. We follow the analysis of Taylor (2009), as presented in 'A secular world', to describe the development of secularisation as well as its meaning for the identity development of people today. According to Taylor, it is the change in the process of identity construction that has had - and still has - a huge impact on the way people position themselves in their context. The main principle according to which a person's position in society is organised and structured (the hierarchical principle of status and belonging to a certain family, belonging to a group of respected craftsmen, belonging to a religious community) fades away to make place for the principle of the dignity of all human beings, the dignity of citizens in a democratic society. In a democratic society there is equal recognition of the dignity of every individual. Recognition of this dignity becomes an important issue because this kind of dignity does not go without saying, like in earlier days when a person's status was based on this person's place of birth; in modern times recognition is something you have to gain, and in the attempt to gain it you might fail (Taylor 1989, 2007). The result of the process of modernisation is an individualised identity. While in earlier days knowing what to do to be a good member of society was based on the knowledge of good and evil as this was transmitted in the Christian tradition, these days knowing what to do is the result of an inner process of searching in the Self for 'the source of the good'. This inner process gives rise to stress because of the need for authenticity and, as a process, leads to an individualised way to be 'a good human': 'I do it my way'. In the event that a person cannot find an authentic and unique way, this may result in the statement: 'I miss the point of my life'. 'In articulating the point of my life, I am also defining my Self' (Taylor 1991:29). However, according to Taylor, this process can only be successful in dialogue with 'significant others': 'This crucial feature of human life is its fundamentally dialogical character' (Taylor 1991:30).

We define our identity always in dialogue with, sometimes in struggle against, the things our significant others want to see in us. Even after we outgrow some of these others - our parents, for instance - and they disappear from our lives, the conversation with them continues within us as long as we live (VerhofstadtDenève 1995, see also Hermans \& Gieser 2012). We need relationships to fulfil, but not to define, ourselves. (Taylor 2009:33)

Following Taylor, we conclude that authenticity and recognition are two sides of the same coin. It seems that it is precisely this difference that figures as a constitutive part in a constructive dialogue whereby identity - and also professional identity - is constructed, which has been ignored, glossed over and assimilated into a dominant or majority identity. This assimilation is the cardinal sin going against the ideal of authenticity (Taylor 2009:38), which leads to a false homogeneity (Taylor 2009:44). The need to have one's dignity recognised, not only as a person but even more so as a beginning professional, and the need to be recognised as someone different and autonomous, makes students vulnerable. Professors and lecturers who are aware of this vulnerability, bearing responsibility for the development of their students, have to take care of them while, at the same time, they need to invite their students to leave their comfort zone. A pedagogy of challenge and care, a so-called provocative pedagogy (Ter Avest \& Bertram-Troost 2009; Ter Avest et al. 2012), materialises this dual focus. The same challenge, arising from vulnerability, poses itself for professors and lecturers. The loss, to a certain extent, of cultural identity is the way out of the comfort zone of a wellrespected professor or lecturer in RE, who functions in the Dutch plural context. Subsequently, for contemporary RE teachers in secondary education, it is the will and courage to face one's vulnerability that is preconditional for facilitating (the development of) new kinds of normative professionalism (cf. Roy, in: Oudenampsen 2014).

Identity development understood in terms of a development of commitments is articulated by Marcia (1980). Marcia distinguishes between commitments in private life (like a commitment to relationships with parents and friends, and the commitment to a secular or religious worldview) and commitments in professional life (like a commitment to training for a particular profession and commitment to political decisions, rules and regulations which apply to one's professional field). Included in our approach of identity development are the peer group and the membership organisations which constitute the life world of youngsters, and which are a major influence on their (religious) identity development (Bakker \& Ter Avest 2008; Jackson 1997; Marcia 1980). According to Marcia, identity develops initially in four statuses which relate to each other in a hierarchical order: a development starting at the status of foreclosure, proceeding through diffusion and a status called moratorium, and which is concluded by arriving at identity achievement. Crucial in this process of identity development, according to Marcia, is the possibility to explore because of the need of the individual to explore a variety of value orientations and worldviews, and their respective positions towards existential questions. This kind of exploring can be done, for example, by taking the perspective of 'the other' or, to put it in another way, by 'walking in the shoes of the other' (Roebben 2009), which makes it possible to arrive at deeply felt commitments. In Marcia's view, such deeply felt commitments are preconditional for a stable status of identity achievement to emerge. This phase of exploration, which could also be named a phase of research, results in stable commitments, with regard to a choice of profession ${ }^{2}$, a political stance and a 'companion for life'. In our view, knowledge about and adaptation to this specific explorative phase in the identity development of students is crucial for academics to perform well at TTIs.

This last sentence, formulated in a kind of statement: 'We as a team decided that knowledge about and adaptation to the

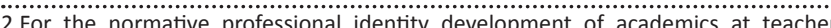
training institutes, it is of utmost importance traing inthin their person traced within their personal commitment are brought into a flexible balance: their personal commitment to a (religious or secular) worldview, to their teacher training institute and to the value orientation of society as a whole (Van Ewijk \& Kunneman 2013; Kelchtermans 2013). 
explorative phase in the identity development of students should be taken as our guide while preparing lessons', can be seen as a valuation. 'Valuation' is a core concept in the Valuation Theory and the Dialogical Self Theory - the Dutch psychology professor Hubert Hermans is the founding father of these theories (Hermans \& Gieser 2012; Hermans \& Hermans-Jansen 1995).

According to the Valuation Theory (VT), persons are motivated in their behaviour by two basic motives: the S-motive aiming at strengthening self-awareness and selfesteem, and the O-motive directed towards care for others and belongingness in relation to others. It is through affectrelated responses to persons or situations that the $\mathrm{S}$ - and O-motives become visible. For example, the affect of 'tenderness' refers to the O-motive, and the affect of 'pride' refers to the S-motive - in a positive way. Valuation Theory states that a person can experience different feelings at the same time, or the same feelings in a similar context. For example, walking in the woods with my dog gives me a feeling of happiness while, at the same time, I feel powerless when my dog starts chasing a rabbit, quickly followed by another feeling - pride - when my dog immediately returns to me when I call it.

Following the line of thought in the Dialogical Self Theory, different feelings represent different 'voices' in myself, which are voices that can flexibly change position in my Self as a result of a change in context. I am a multi-voiced Self. The voice of 'my mother' comes to the fore (e.g. ironing my clothes, I remember her showing me how to do that), but in the context of a seminary for colleagues the critical voice of 'my mother' will make place for the voice of 'my professor', whose constructive criticism is still supportive in my mind. By way of scoring on a validated list of affects, the strength and direction of the motivational commitment (positive, i.e. P-directed, or negative, i.e. N-directed) is visualised, along with the preference for or dominance of the S- or the $\mathrm{O}$-motive, in a certain situation or towards a certain person.

To challenge the academics and unlock their longstanding beliefs, and inspired by the concept of the multi-voiced Self in our research, we make use of an instrument called the Self Confrontation Method. At the basis of this instrument lie the Valuation Theory and the Dialogical Self Theory, presented by Hermans and Hermans-Jansen (1995) and reviewed, renewed and extended by Hermans and Hermans-Konopka (2010) and Hermans and Gieser (2012).

\section{Research methodology}

Originally, the Self Confrontation Method was constructed for individuals, for therapeutic aims. This instrument has been adapted for groups and organisations (SCM-org; Van de Loo 2010, 2012; Wijsbek 2009). The Self Confrontation Method starts with an interview when used for a person, or with a focus group interview when used for a team. People are invited to tell about their life and 'critical incidents' which took place, a narrative triggered by a so-called ontlokker (a question or a statement with an 'eliciting' function). Ontlokkers direct the story telling activity, by specifically asking the interviewees about situations or persons that were important for them in the past (yesterday marking the beginning of the past), or are important to them today, or are expected by the interviewees to be important for them in the future. These situations may have occurred within the family, at work or with friends. With the help of the interviewer, the responses of the interviewees are summarised in so-called valuations: short statements representing the core of the response. In general, the outcome of the interview is a list of 20-30 valuations. In addition, each person is invited to relate these single valuations to a list of 16 validated affects (like tenderness, loneliness, care, anger). The strength of the affect in a particular case is represented by a number between 0 and 5; 0 means that the valuation has no relation with this particular affect and 5 means that the affect is very strong in the situation which is described in the valuation. Every valuation can give rise to a mix of feelings, a characteristic coined as emo-diversity. A flexible balance between positive and negative feelings is required for personal well-being and resilience (Schwartz 1986).

For example, the valuation 'We as a team decided that knowledge about and adaptation to the explorative phase in the identity development of students should be taken as our guide while preparing lessons' can give rise not only to strong feelings of anger ( 5 because I have to submit my own ideas to the decision of the team), but also to strong feelings of pride ( 5 because I feel an expert in working according to a theoretical framework, and in working with related concepts).

The scoring of all valuations shows a pattern, which through its correlations gives insight into the directedness of the person's or the group's motivational commitment: whether it is mainly Self- or Other-directed, whether this is mainly in a positive or in a negative way, and with the mix of feelings on which the directedness is based.

Our research population, the existent team responsible for the construction of a new curriculum, consists of a group of 17 academics, 14 men and 3 women. Nearly all of them are theologians, with the exception of two persons, who have a different academic specialisation. One of the participants is trained in methodology and the other is educated as a psychologist. All of them are familiar with the Roman Catholic tradition - to a greater or lesser extent.

In this intervention research, qualitative research instruments were used, like focus group interviews and individual writing tasks. During the research process (March-May 2014), these academics worked alternately as individuals, in pairs and in small groups, in four sessions of $2 \mathrm{~h}$ each. The interventions in these sessions were developed by the researchers, a theologian/educationalist and a psychologist of religion. They also prepared these meetings, chaired them and wrote the reports. 
To investigate the positionality of the academics/team members with regard to their teaching activities, all of them are invited upon the first meeting - as a first intervention - to write down a moment taken from their teaching practice that they would label as an example of 'good education'. They discuss these examples in pairs. Next, during a second team meeting, we introduced conceptualisations of 'good education' which were developed, among others, by the pedagogue Gert Biesta (2012). We presented and discussed the distinction between technical and normative professionalism, in the way we have elaborated this distinction in our own Utrecht Research group (Bakker 2014; Bakker \& Wassink 2015; see also Van den Ende \& Kunneman 2007; Van Ewijk \& Kunneman 2013). The reports of the first and second meeting and its interventions, as well as the reports of the discussions which followed (focus group conversation), are analysed by way of 'close reading ${ }^{\prime 3}$ (Rubin \& Rubin 2003). Characteristic statements emerging from these discussions are re-formulated in so-called valuations. ${ }^{4}$ These valuations are the input in the SCM${ }^{5}$-related instrument, the SCM-org; this constitutes the third intervention pertaining to the third session, conducted according to the multi-facetted and multi-methods design of our research project. The fourth intervention, which pertains to the fourth session, is the invitation for academics to act as co-researchers in the process of analysing and interpreting the results of the scores of the standardised SCM-org instrument (the empirical data). These four interventions are designed to get, firstly, insight into the individual positionality of academics, that is, on a personal level with regard to their adherence to the Roman Catholic tradition; secondly, to get insight into the team's positionality with regard to the education and training of students in the Roman Catholic Training Institute (RC-TI) and the RC-TI as a whole and, finally, to acquire insight about the relation of this positionality to the Roman Catholic church and the Roman Catholic religious tradition as a whole. By means of these interventions, the team members gain insight in the 'voice' of tradition, how it manifests in their own lives and in the training institute.

In this article the focus is on answering the research questions through intensive collaboration with academics who take on the role of co-researchers. They are involved in the process of analysing and interpreting the data resulting from the online scoring of the valuations, and by this manner of participation a strong feeling of commitment to the outcomes is established.

For the construction of the set of valuations, we made use of the examples of 'good practice' which the team members provided and of the theoretical input collected during the team meetings. Next, we drew on the reports about the focus group conversations which followed (the third intervention which took place in team meetings), during which academics

3.'Close reading refers to repeated reading and accordingly marking the pivotal concepts of a text, categorising and coding. For an extensive description of this process, see Rubin and Rubin (2005:206-209).

4.These valuations can be seen as 'findings' of the preceding interventions. However, at the same time the analysis of these valuations by the lecturers as co-researchers is at the heart of our innovative methodology.

5.SCM: Self Confrontation Method (Hermans \& Hermans-Jansen 1995) jointly discussed the core characteristics of the present-day and future teacher training in RE.

Before we introduce the tasks which we presented to the team members in order to invite them to co-operate as coresearchers, we provide examples of significant valuations, in the way they emerged out of the examples of good practice and the theoretical and practice-oriented focus group conversations ${ }^{6}$ :

2. Society demands that I include the culture of young people in my lessons.

3. An RE teacher trained at the RC-TTI is familiar with the Catholic tradition and experiences this tradition in an authentic way.

5. An RE teacher educated at the RC-TTI is trained both as a theologian and as a pedagogue, and is thus well equipped to explore existential questions with students in secondary education.

16. An RE teacher trained at the RC-TTI is, first of all, a theologian. 18. Students of the RC-TTI learn about the Catholic tradition, and about other religious traditions besides.

23. FUTURE: We, as the RC-TTI, are highly respected in Europe.

The sum total of 25 valuations constitutes the team's 'system of valuations'.

The whole system of valuations is shown to the team by means of an online presentation. More specifically, every valuation out of 25 is screened separately, and is shown in consecutive order to the single team members (the academics), asking them to relate each of the 16 validated affects to the situations that are described. Every team member is asked to score - on a scale from 0 to 5 - to what extent the separate valuations elicited particular feelings out of a list of 16 feelings (referring to Self- and Other-motive, and related to Positive and Negative feelings).

The 25 valuations are shown on the screen in consecutive order, and underneath the valuations the affect terms appear one by one, whereby the team members are given the possibility to enter a score between 0 and 5 for every single affect term.

The 16 feelings are listed below, with their validated relation to the Self- or Other-motive, including the Positive or Negative-direction of the respective affect term. It should be pointed out that neither the S- or O-directedness, nor the $\mathrm{P}$ - or $\mathrm{N}$-direction is shown to the respondents.

- Self-motive: Self-Esteem, Strength, Self-Confidence, Pride

- Other-motive: Care, Kindness, Friendship, Team-Spirit

- Positive: Enjoyment, Satisfaction, Inner Calm, Trust

- Negative: Inferiority, Anxiety, Disappointment, Anger

The scores of the participating academics are analysed by using software engineered by Psycro BV/SCMPro Service. ${ }^{7}$

6.The numbers in the paragraph below point to the sequence in the system of valuations.

7.Psycro BV/SCMPro Service was purpose-built for the analysis of SCM-scores, in close cooperation with the founder of the Valuation Theory and Dialogical Self Theory. 


\section{Presentation of data and results of the analysis}

We present the data of our study which focuses on the development of insight into the 'voice of tradition(s)' by our individual team members and the team as a whole, with the help of scatter diagrams which represent the reactions of our respondents to the so-called valuations. These valuations challenged our participants to explore their positionality regarding 'the voice of tradition' and their personal commitment to the old and the new curriculum (i.e. still to be developed). More specifically, it was their positionality in the past, in the present and for the future (i.e. the positionality they wish for in the future) that was explored by means of the valuations.

There is a high correlation (0.94) between the scores given to affects which relate to the actual situation (the situation at the time of the scoring), and the scores given to affects which relate to the future situation. The following valuations show high correlations (higher than 0.90) with both of these situations - future as well as current situation:

3 A teacher trained at the RC-TTI knows and experiences the Roman Catholic tradition from an insider's perspective.

5 An RE teacher educated at the RC-TI is trained both as a theologian and as a pedagogue, and is thus well equipped to explore existential questions with students in secondary education.

7 Alumni of the RC-TTI are aware of their own positionality regarding the Roman-Catholic tradition.

9 The Roman Catholic teacher is loyal to his school and to the church.

14 The RC-TTI promotes the grading up of the status of the subject RE.

15 A teacher trained at the RC-TTI initiates at the school the discussion about 'good education.

20 FUTURE: Working closely with the coach at the school, I am responsible for the development of 'the good Catholic teacher'.

22 FUTURE: Students are all ears for any teacher trained at the RC-TTI.

What these valuations have in common is their high scores on feelings related to the Self-motive, paired with high scores to the Other-motive - though these latter scores are lower than the scores on the Self-motive. One could say that the Self- and Other-motive, representing care for oneself as a professional and the directedness towards others, are interwoven in the conceptions which academics have about the contemporary and the future reality of the RC-TTI.

Regarding the Self-motive, or care for one self, the mean scores for the feeling of Self-Esteem are generally the highest (3.32), while those for Pride are the lowest (3.06). Self-Esteem gets the highest mean score (4.69) for the valuation no. 5: $A n R E$ teacher educated at the RC-TTI is trained both as a theologian and as a pedagogue, and is thus well equipped to explore existential questions with students in secondary education. The lowest mean score (1.13) for Self-Esteem is given to valuation no. 4: The Bishop is the person who is primarily responsible for the quality of the RC-TTI. Like Self-Esteem, Pride gets the highest score (4.25) on valuation no. 5. The lowest mean score (1.00) for Pride is for valuation no. 10: The professional body is dominated by senior academics. Self-Esteem and Pride, though, are undermined by Anxiety (corr. -0.91 and -0.90 , respectively) and Disappointment (corr. -0.97 and -0.93 , respectively). These scores might point to a possible conflict between the professional autonomy that academics favour, and their disappointment about the restrictions that are imposed on them - because of the dominance of clerical and senior participants - in the discussion about the future curriculum of the RC-TTI. Such a conflict might hinder - but might also have a stimulating effect on - the reformulation of the relationship between church and educational institute.

Regarding the Other-motive, or directedness towards others, the mean scores for the feeling of Team-Spirit are generally the highest (2.76) and the feeling of Kindness gets the lowest mean score (2.41). Team-Spirit gets the highest score (4.00) on valuation no. 20 FUTURE: Working closely with the coach at the school, I am responsible for the development of 'the good Catholic teacher'. The lowest mean score (1.44) for TeamSpirit is for valuation no. 10: The professional body is dominated by senior academics. The highest mean score for Kindness (3.06) is given to valuation no. 12: The RC-TTI encompasses knowledge about AND experience with spirituality. The lowest mean score (1.19) for Kindness, like for Team-Spirit, is given to valuation no. 10: The professional body is dominated by senior academics. Team-Spirit and Kindness are both undermined by feelings of Anxiety (corr. -0.83 and -0.87 , respectively) and Disappointment (corr. -0.83 and -0.87 , respectively). These scores might shed light on a matter that concerns all the staff members, namely the apparent discrepancy between a longing for close co-operation and shared responsibility with the coaches at the schools, and the dominance of senior academics who generally are of the opinion that, at the end of the day, they - and only they contribute to the professional qualities of RE teachers who pass their exams at the RC-TTI. This discrepancy needs to be elaborated upon because it might hinder the innovation of the curriculum at this institute.

In three scatter diagrams, the intensity of the scores is shown in its positive or negative strength. The first scatter diagram gives an overview of all the positions of a single person. For every single person, this diagram shows how every valuation out of 25 (by way of the scores) is situated in the negative side (the upper left side) of the scatter diagram, and how the other valuations are positioned in the positive side (the right down side) of the scatter diagram. For the greater part, the respondents relate in a negative way to the valuations no. 1 (A teacher trained at the RC-TTI transmits truth claims to pupils at secondary schools in the way this is prescribed by the Roman Catholic tradition), no. 4 (The Bishop is the person who is primarily responsible for the quality of the $R C-T T I$ ) and 10 (The professional body is dominated by senior academics). One dissonant voice is heard. This person values the transmission of Roman Catholic truth claims to pupils in a positive way. 
The second scatter diagram shows the visualised presentation of one single valuation, and how the single group members are positioned (by way of their scoring) in regard to this specific valuation. In our research, this showed, for example, with regard to valuation no. 7: Alumni of the RC-TTI are aware of their own positionality regarding the Roman-Catholic tradition. In general, the respondents are situated at the positive side of the scatter diagram; only one person in the negative side of the diagram is the dissonant voice regarding this specific valuation. In general, this diagram presents a homogeneous picture in the sense that the respondents agree and are all positioned either on the negative or the positive side of the diagram. The presentation of some single valuations pictures the spread of the positive and negative position of the different single group members. More or less isolated dissonant voices of group members are seen in seven of the in the scatter diagrams presented valuations. Depending on the valuation, different persons have a dissonant voice.

The third diagram gives an overview of the group scores. This diagram shows how the different appreciations of the valuations are scattered within the space of the diagram. This scatter diagram shows, for example, that the team scored a specific group of valuations in a generally positive way:

3 A teacher trained at the RC-TTI knows and experiences the Roman Catholic tradition from an inside perspective.

7 The teacher graduated at the RC-TTI is well aware of her/his own positionality regarding the Catholic tradition.

12 The RC-TTI encompasses knowledge about AND experiences with spirituality

14 The RC-TTI promotes the grading-up of the subject of RE

15 A teacher trained at the RC-TTI initiates at the school the discussion about 'good education'.

18 Students at the RC-TTI know about the Catholic tradition and other worldview traditions in the Netherlands.

20 FUTURE: Together with the coach of students' teaching practice I am responsible for the development of 'the good Catholic teacher'.

22 FUTURE: Students are all ears for any teacher trained at the RC-TTI.

These valuations share a focus on personal development and commitment, and another group of valuations in a negative way:

1 A teacher trained at the RC-TTI transmits truth claims to pupils at secondary schools in the way this is prescribed by the Roman Catholic tradition.

4 The Bishop is the person who is primarily responsible for the quality of the RC-TTI.

10 The professional body is dominated by senior academics.

These valuations revolve around an attitude of resisting topdown/external influences on the teaching content of RE professionals and their positionality regarding the Roman Catholic tradition. Professional autonomy visibly turns out to be a preferred position.

These scatter diagrams are analysed with the co-operation of the academic scholars themselves, by including them as co-researchers in our study (the fourth intervention).
To familiarise them with their task as co-researchers, we developed assignments in which they were asked to analyse and interpret the outcomes of their reactions ('scoring') to the valuations (Hermans \& Hermans-Jansen 1995).

One of the assignments was to discuss with each other the different positions a person her/himself and the colleagues occupy with regard to valuation number $x, x 1, x 2$ and so forth. At this stage of the co-researching process, the valuations with a mixed picture in the scatter diagrams were brought into the discussion. Questions like 'How can the difference in the scoring of valuation no. $x$ be interpreted?' In this phase of the analysis, special attention was given to the 'dissonant voices' about each of these valuations (cf. Ter Avest 2014a; Van De Loo 2012).

Another assignment invited the team members to compare the team's positioning of valuation $x$ with how they positioned valuation $y$, or with the positioning of a group of valuations. 'What differences and/or commonalities do you notice?' 'What is your interpretation of the differences and/or commonalities?' What is the meaning of your interpretation for the actual and new-to-be-developed curriculum of the teacher training institute?

As a result of the analysis and the interpretations of the academics that were involved in it, we wrote a 'state of the art' in which we formulated the different positions with regard to the teams' system of valuations, and which summarised the consequences of this positionality for a new curriculum-to-be-constructed. The text focused on a number of contrasting feelings: feeling confirmed in one's positioning, versus being 'violated', or being invited to leave the comfort zone to enter the internal and external dialogue on autonomy versus restrictions, that is, restrictions on the part of the Bishop, or limitations resulting from the close cooperation with coaches working at secondary schools. A dialogue on these topics, which takes the dissonant voices into account, is preconditional for the work that has to be done for the new curriculum-to-be-constructed, a curriculum with the aim to recognise and include contemporary youth sub-culture in the construction of the identity of an RE teacher in secondary education (cf. Knausgard 2014). Raising hopes for the success of the dialogues to come is the shared commitment for curriculum innovation, as this is seen, for example, in the homogeneous picture that the diagram shows for valuation no. 20: FUTURE: Working closely with the coach at the school, I am responsible for the development of 'the good Catholic teacher'. Shared feelings on this aspect of the new curriculum might be a solid ground to overcome the tensions.

\section{Conclusion, discussion and recommendations}

Based on our observations during this process, the positive feedback of the academics involved and the results of the analyses of the data, we answer our research questions in the following way. We conclude that the Dialogical Self Theory-based method of the Self Confrontation Method for 
organisations has shown itself to be a challenging instrument to invite academics involved in the process of data construction and data analysis. However, much time had to be invested (four team meetings of approximately $2 \mathrm{~h}$, and at least $1 \mathrm{~h}$ of homework for each of the participants to score the valuations) in the process of reflecting on personal and team positionality. In particular, the aspect of not being analysed, but being involved and committed to the process of analysing in the role of a coresearcher, was not only innovative from a methodological point of view but also highly appreciated by the academics of this specific teacher training institute for RE teachers. Awareness was raised through clarification of the theoretical framework of the Dialogical Self Theory about the close relation between a person's and the team's commitment (cf. Verhofstadt-Denève 1995) and the (im)possibility to realise a new curriculum (cf. Hargreaves \& Fullan 2012). In the context of the Netherlands as a pluralistic society, innovation of the training of RE teachers at teacher training institutes may be urgent. The realising of such an innovation depends not only on the degree of motivation and commitment, but, to a large extent, also on capabilities of the academics involved to reflect on their individual and group positionality and take the consequences. For the persons involved, the Self Confrontation Method for organisations raised their awareness of their own and their colleagues' different ways and different intensities of commitment (their actual way of interpreting and adhering - in some way or another - to the Roman Catholic tradition) and their motivation for innovation of the curriculum. In addition, as the facilitation of dialogue is at the heart of the Dialogical Self Theory and its methods, the Self Confrontation Method for organisations also informed colleagues about each other's competencies with regard to the team effort of innovation. Not only for academics in RE the use of the Dialogical Self Theory-related instruments might be helpful, but also in disciplines other than RE and Theology. The Self Confrontation Method for organisations is a promising instrument to research and transform academics' positionality in their current and future (possibly innovative) approach of their work. The transformative power of this instrument is in its dialogical approach, doing justice to and recognising each participant's multi-voiced contribution regarding the challenges faced by a team of academics.

The challenge that lies at the heart of this method of coresearching is the introduction of the characteristics of Dialogical Self Theory and its Self Confrontation Method, in a condensed way in a team meeting of only $2 \mathrm{~h}$. A minimal degree of familiarity with the core concepts of this theoretical framework is preconditional to come up to the expectations of this process. This must be done by an expert in the field of the Dialogical Self Theory and its instruments like the Self Confrontation Method for organisations in such a way that team members are well enough informed to make sure that none of them feel violated at some point, but, on the contrary, all feel invited and empowered to engage in the analysis of the constructed data. With our theoretical approach of the Dialogical Self Theory, we contributed to the body of knowledge regarding preconditions which have to be in place, in order for academics to commit to joint efforts of innovation in education. However, more research about this dialogical type of collaboration in data construction and data analysis is required.

In addition to including academics in the process of formulating the so-called valuations, and in the process of analysing and interpreting results - a process that, in itself, already gave much insight - we recommend to include the research population in a validation process, a crucial aspect of the Self Confrontation Method as this was developed primarily. As a monitoring process, the validation process is important, relevant and efficient. It performs these functions not only in terms of the sustainability of the results, but even more so when it comes to minimising any feelings of violation for each person and with regard to the team's comfort zone, and to maximise engagement in the implementation phase of the new curriculum. The coaching of academics, which revolves around the stimulation of a growing awareness, is an ongoing process for every person and for the team as a whole, and a necessary one to keep up with developments regarding the place of religion in society. To be capable to educate the next generation of RE teachers, academics should work continuously on their own authentic positionality with regard to the core characteristics (the valuations) of the old and new to-be-constructed curriculum. This is work in progress. These scholars need to strengthen their will to leave their own comfort zone, and their resolution to create a shared commitment towards the new curriculum. Last but not least, reflection is needed upon the work in progress in order to learn from their shared history on their way to the future of a Catholic Teacher Training Institute as a highly respected institute in today's Europe.

\section{Acknowledgements Competing interests}

The authors declare that they have no financial or personal relationships that may have inappropriately influenced them in writing this article.

\section{Authors' contributions}

C.B. was the project leader and responsible for the project design. I.T.A. was responsible for the theoretical framework of the Dialogical Self Theory and its Self Confrontation Method for teams.

\section{References}

Bakker, C., 2014, Het goede leren. Leraarschap als normatieve professie, [Good learning; Teaching as a normative profession], Public lecture given at Utrecht University/Utrecht University of Applied Sciences, Utrecht.

Bakker, C. \& Wassink, H., 2015, Leraren en het goede leren. Normatieve professionalisering in het onderwijs, [Teachers and good learning; Normative professionalization in education], Utrecht University, Utrecht.

Bakker, C. \& Montesano Montessori, N. (eds.), 2016, Complexity in education: From horror to passion, Sense Publishers, Rotterdam.

Bakker, C. \& Ter Avest, I., 2008, 'Opnieuw denken: De visie van Marcia op identiteitsontwikkeling [Thinking anew: Marcia's view on identity development]' in K. Meijlink c.s. Reflecties op multiculturele identiteit. Onderwijspakket Stel je voor; De kunst van het beleven en ontmoeten. Identiteitsontwikkeling in de je voor; De kunst van het beleven en ontmoeten. Identiteitsontwikkeling in de the art of experience and encounter], pp. 7-15, Marnixacademie, Utrecht. 
Biesta, G., 2014, The Beautiful Risk of Education, Routledge, London/New York.

Du Preez, P., 2011, 'Reconciliation through dialogical nostaligia in post-conflict societies: A curriculum to intersect', Compare: A Journal of Comparative and International Education 44(1),117-135, https://doi.org/10.1080/03057925.2013. 859875

Hargreaves, A. \& Fullan, M., 2012, Professional Capital. Transforming teaching in every school, Columbia University, Teachers College Press, New York.

Hermans, H.J.M. \& Gieser, T. (eds.) 2012, Handbook of dialogical self theory, Cambridge University Press, Cambridge CB2 8RU, UK.

Hermans, H.J.M. \& Hermans-Jansen, E., 1995, Self-Narratives. The construction of meaning in psychotherapy, The Guilford Press, New York NJ 10012.

Hermans, H.J.M. \& Hermans-Konopka, A., 2010, Dialogical self theory. Positioning and counter-positioning in a globalizing society, Cambridge University Press, Cambridge CB2 8RU, UK.

Jackson, R., 1997, Religious education. An interpretive approach, Hodder and Stoughton, London.

Jackson, R., 2011, 'Special Issue: Religion, education, dialogue and conflict: The REDCo Project', British Journal of Religious Education 33(2), 105-109.

Jackson, R., Miedema, S., Weisse, W. \& Willaime, J.-P. (eds.), 2007, Religion and education in Europe: Developments, contexts and debates, Waxmann, Münster.

Kalsky, M. \& Pruim, F., 2014, Flexibel geloven. Zingeving voorbij de grenzen van religies [Flexible faith. Construction of meaning crossing the borders of religious traditions], Skandalon Uitgeverij, Vught.

Kelchtermans, G., 2009, 'Who I am in how I teach is the message. Self-understanding, vulnerability and reflection', Teachers and Teaching: Theory and Practice 15(2), 257-272. https://doi.org/10.1080/13540600902875332

Kelchtermans, G., 2013, De leraar als (on)eigentijdse professional. Reflecties over de 'moderne professionaliteit' van leerkrachten [The teacher as a present-day/outdated professional, Refle
Onderwijsraad, Den Haag.

Knausgård, K.O., 2014, 'Ik ben niemand [I am nobody]', Vrij Nederland, Vol. 37, September 13, pp. 71-72.

Korthagen, F.A.J., 2001, Linking practice and theory. The pedagogy of realistic teacher education, Lawrence Erlbaum Associates, London, in close cooperation with Kessels, J., Koster, B., Lagerwerf, B. \& T. Wubbels.

Marcia, J.E., 1980, 'Identity in adolescence', in J. Adelson (ed.), Handbook of adolescent psychology, pp. 159-187, Wiley, New York.

Oudenampsen, M., 2014, 'De mars van Gods stoottroepen [The march of God's army]', De Groene Amsterdammer 138(37), pp. 26-29.

Roebben, B., 2009, Seeking Sense in the City; European Perspectives on Religious Education, Lit Verlag, Berlin.

Rubin, H.J. \& Rubin, I.S., 2003, Qualitative interviewing. The art of hearing data, Sage, Thousand Oaks, CA.

Schwartz, R.M., 1986, 'The internal dialogue. On the asymmetry between positive and negative coping thoughts', Cognitive Therapy and Research 10(6), 591-605. https://doi.org/10.1007/BF01173748

Taylor, C., 1989, Sources of the self, the Making of Modern Identity, Cambridge University Press, Cambridge CB2 2RU, UK.

Taylor, C., 1991, The malaise of modernity, House of Anansi Press, Toronto.
Taylor, Ch. 2009, A secular age, The Belknap Press of the Harvard University Press, Cambridge, Massachusetts, and London, England.

Ter Avest, I., 2014a, 'Value orientation of teams', Presentation at the Dialogical Self Conference, The Hague 19-22 August.

Ter Avest, I., (ed.), 2014b, Af en Toe Stemmen [Attuning and adapting to the other's Voice], Gopher B.V., Amsterdam.

Ter Avest, I., Bertram-Troost, G.D. \& Miedema, S., 2012, 'Provocative pedagogy, or youngster need the brain to challenge world view formation', Religious Education 107(4), 356-370.

Ter Avest, I., Jozsa, D.-P., Knauth, T., Rosón, J. \& Skeie, G. (eds.), 2009, Dialogue and conflict on religion. Studies of classroom interaction in European countries, Waxmann, Münster.

Ter Borg, M., Borgman, E., Buitelaar, M., Kuiper, Y. \& Plum, R. (eds.), 2008, Handboek Religie in Nederland; Perspectief, overzicht, debat [Handbook Religion in the Netherlands; Perspectives, overview, debate], Meinema, Zoetermeer.

Van De Donk, W.B.H.J., Jonkers, A.P., Kronjee, G.J. \& Plum, R.J.J.M. (eds.), 2006, Geloven in het publieke domein. Verkenningen van een dubbele transformatie, [Religion in the public domain. Explorations of a double transformation], University Press, Amsterdam.

Van de Loo, R., 2012, 'De stem van de dissonant: Stimulering van meerstemmigheid en dialoog bij teamontwikkeling', [The voice of the dissonant: Challenging multivoicedness and dialogue in team development], in F. Meijers (ed.), Wiens verhad telt? Naar een narratieve en dialogische loopbaanbegeleiding [Whose story are we talking about? Towards a narrative and dialogical career coaching], Uitgeverij Garant, Antwerpen, pp. 219-236.

Van Den Ende, T.M.L. \& Kunneman, H.P., 2007, 'Normatieve professionaliteit en normatieve professionalisering Een pleidooi voor conceptuele verdieping', [Normative professionalism and normative professionalisation. A plea for conceptual clarification], in G. Jacobs, R. Meij, H. Tenwolde \& Y. Zomer (eds.) Goed werk. Verkenningen van normatieve professionalisering, pp. 68-87, SWP, Amsterdam.

Van der Want, A., Bakker, C., Ter Avest, I. \& Everington, J. (eds.), 2009, Teachers responding to religious diversity in Europe. Researching biography and pedagogy, Waxmann, Münster, New York, München, Berlin.

Van der Zande, E., 2018, 'Life orientation for professionals. A narrative inquiry into morality and dialogical competency in professionalisation', PhD thesis, Utrecht University, Utrecht, The Netherlands.

Van Ewijk, H. \& Kunneman, H. (eds.), 2013, Praktijken van normatieve professionalisering [Praxis of normative professionalization], SWP, Amsterdam.

Verhofstadt- Denève, L., 1995, Zelfreflectie en Persoonsontwikkeling: Een handboek voor ontwikkelingsgerichte psychotherapie [Self-reflection and personal development: A handbook for development-oriented psychotherapy], Uitgeveri] Acco, Leuven

Versteegt, I., 2010, 'Diversiteit in de klas - perspectief van de leerkracht', [Diversity in the classroom - from a teacher's perspective], PhD thesis, Utrecht University, Utrecht, The Netherlands.

Vloet, K., Jacobs, G. \& Veugelers, W., 2016, 'Teacher's professional identity development as a dialogical process', Paper of the Dialogical Self Conference, September 7-10, Poland, September 7.

Wijsbek, J., 2009, De dialogische organisatie [The dialogical organisation], Koninklijke Van Gorcum, Assen. 